\title{
Profiling the Reading Habits of Children in Singapore
}

\author{
Shaheen Majid \\ Associate Professor \\ Nanyang Technological University \\ Singapore \\ Venus Tan \\ Former Graduate Student \\ Nanyang Technological University \\ Singapore
}

The leisure reading contributes significantly in improving language competencies of children. This study investigates the reading habits and preferences of children, motivations behind reading, and their attitude towards reading. A pre-tested questionnaire was used for collecting data and 440 upper primary students participated in the study. The findings suggest that a majority of the participating students were motivated to read for academically-related reasons, such as to improve language skills and to obtain better grades in examinations. Reading was the third most preferred leisure activity after hobbies and playing on computer or the Internet. It was also found that girls were generally more avid readers than boys. This paper offers certain suggestions for promoting reading habits among children.

\section{Introduction}

The reading habits of children have long been a matter of much interest to educators, parents, librarians, publishers, and other stakeholders. An understanding of the reading habits and preferences of children would help them to take necessary measures for promoting reading among children. It is widely acknowledged that the life-long habit of reading can best be inculcated and nurtured at an early age. It is, however, a general observation that there is an overemphasis on study-related reading thus ignoring the recreational or free voluntary reading among children. With increasing pressure on children to perform well academically, it is not surprising that children often associate books and reading with learning, schoolwork, school projects, and passing examinations. Cheah (1998) noted that while students in Singapore will not hesitate to read school-related materials, getting them to become life-long readers and to read for pleasure remains an uphill task.

Studies have shown a positive correlation between students' free time reading for fun and their reading achievement (National Center for Education Statistics, 1993; Shefelbine, 1998). Pleasure reading furthers the development of reading as a life-long habit which strengthens both language skills and fluency. Royce (1995) noted that 
children improve their reading skills when they enjoy reading, that is, when they read for pleasure. Many studies have revealed that free voluntary reading results in improving reading comprehension, writing style, vocabulary, grammar, and spelling. Cunningham and Stanovich (1998) reported that reading volume, both inside and outside the school, has a significant impact on the development of reading speed and fluency, vocabulary, general knowledge, overall verbal ability, and academic achievements. An international comparative study of reading literacy among children in 35 countries showed that the more often a child reads for fun, the higher is his/her average reading literacy scale score (Ogle et al. 2003).

There are many factors that motivate reading among children. An international survey has shown that nearly one-half of the UK students participating in this study said that they read for relaxation while a majority of the children from 12 developing countries revealed that they read books for passing examinations (Books Aid International, 2003). A study of young people in Britain, aged between 11 and 18 years, found that peer influence was the top most reason for reading books (Market \& Opinion Research International-MORI, 2004). A survey of 431 pre-kindergarten through grade eight students in the United States found that 71 percent of the students who perceived themselves as good readers had a positive attitude towards reading while none of the students who regarded themselves as 'poor' readers enjoyed reading (Cosgrove, 2001).

A survey of 8,000 children in Britain, aged 10, 12 and 14 years, found that children had very diverse reading tastes (Hall and Coles, 1999). A similar survey conducted in Denmark on children, aged between nine and twelve years, noted a great deal of variation in children's reading preferences. It was found that, over a span of one month, the children read a total of 1,598 fiction and non-fiction books written by more than 700 authors (Steffensen \& Weinreich, 2000). Among the Singapore children, adventure stories were the most popular, followed by mystery stories (Balasundram, 1991). In Australia, primary school students liked reading action adventure as much as science fiction and fantasy (Woolcott Research, 2001) while in Britain, fantasy fiction was at the top, followed by humour, horror and thriller books (MORI, 2004).

Hall and Coles (1999) reported a trend where fewer books being read as children grow older. A study of reading habits of boys in primary schools found that the number of children who liked reading books dropped by one-third between the ages of five and nine (Times Educational Supplement, 2000). A similar trend was observed in Ireland where over 2200 children, aged between 7 and 16 years, showed a considerable decline in book reading with increasing age (Children's Books Ireland, 2000).

Many studies have shown differences in reading interests based on gender. Steffensen and Weinreich (2000) reported that Danish boys prefer reading suspense, humour, thrillers, and historical books while girls read realistic books, fairy tales and fantasy stories. A study on the information and reading preferences of children in North Carolina concluded that boys like sports, transportation, and military topics whereas girls enjoy reading about arts and crafts, health, fashion, and beauty topics (Sturm, 2003). An earlier study in Singapore reported that boys preferred reading adventure stories while girls like mysteries and fairytales (Balasundram, 1991). Some other studies also suggest that generally boys show lesser interest in reading than girls. 
A survey of 801 young Australians, aged between 10 and 18 years, concluded that females were more likely to enjoy reading books than males (Woolcott Research, 2001). A similar trend was noted in Demark where girls reported spending more time on reading than boys (Steffensen and Weinreich, 2000).

As compared to children a couple of decades back, the young generation now has access to a wide array of leisure activities. There is an intense competition between books and recent innovative, attractive and engaging gadgets for capturing children's time and attention. A study investigating the favourite pastime activities of primary and middle school students in China reported that 'watching TV' was the most popular leisure activity, followed by reading books (Liu, 2000). A similar survey of Primary 1 to Secondary 5 students in Hong Kong found that watching TV and playing computer games were the two most preferred after-school leisure activities (Education Department, 2001). Another survey in Britain concluded that young people, aged between 11 and 18 years, were more likely to watch TV or use the Internet than reading a book (MORI, 2004).

The literature review suggests that several factors, particularly technological changes, are likely to influence reading habits of children. Singapore government is making concerted efforts to prepare a new breed of students who will become lifelong learners. To achieve this objective, a network of public libraries is offering a variety of programmes to inculcate and promote reading habits among children. However, very little is known about the current reading habits and preferences of children in Singapore. The purpose of this study was to investigate attitude, motivation, and preferences of children related to leisure reading. It is expected that the findings of this study will be useful for school and public libraries, teachers, parents, and book publishers in developing appropriate policies and plans for promoting reading among children.

\section{Method}

The questionnaire-based survey method was selected for collecting data for this study. Considering the young age of the potential respondents, those words and phrases were used in the construction of the questionnaire that primary school students were expected to understand easily. The overriding concern in the design of the questionnaire was to ensure that students should not confuse the study-related reading with free voluntary reading. The questionnaire was consisted of three parts and the first section collected demographic information about the respondents. The second section of the questionnaire gathered information about the reading habits and attitudes towards leisure reading. The third section solicited data on respondents' preferences for reading materials, subject interests, and the factors that often encourage them to read.

The questionnaire was pre-tested on five upper primary students, representing the demographic characteristics and age groups of the sample population. The purpose was to determine the appropriateness of language and responses used for constructing the survey questions. All the students participating in the pre-test exercise were able 
to complete the questionnaire without any assistance. However, based on their feedback, some minor changes were made in the questionnaire.

The data for this study was collected from 12 upper primary classes of three schools. The questionnaire was administered personally by the second author to ensure a better response rate as well as to avoid any misunderstanding while providing responses. All the participating schools were requested to set aside 30 minutes for the survey exercise which included a short briefing to the students on the objectives of the study and some basic instructions for completing the questionnaire. The participating students were also reminded that their responses should only cover their free voluntary reading. Each question was read out and the students were encouraged to seek clarification, if needed, before answering the question. A total of 440 upper primary students, aged between 9 and 12 years, from three primary schools in Singapore participated in this study.

\section{Findings}

\section{Demographics}

Table 1 provides the distribution of respondents by their gender and grade level. Student distribution among different grade levels was fairly equal: 142 students from Primary Four, 142 students from Primary Five, and 156 students from Primary Six. Of these, $216(49.1 \%)$ were boys while 224 (50.9\%) were girls. A majority (76.3\%) of the students were Chinese; 16.1 percent were Malays; 5.7 percent Indian, and 1.9 percent belonged to other ethic groups.

Table 1. Distribution of Respondents by Grade Level and Gender

\begin{tabular}{|l|c|c|c|}
\hline \multirow{2}{*}{ Grade Level } & \multicolumn{2}{|c|}{ Number of Respondents } & \multirow{2}{*}{ Total } \\
\cline { 2 - 3 } & Boys & Girls & \\
\hline Primary 4 & 76 & 66 & $142(32.3 \%)$ \\
\hline Primary 5 & 62 & 80 & $142(32.3 \%)$ \\
\hline Primary 6 & 78 & 78 & $156(35.5 \%)$ \\
\hline \multicolumn{1}{|c|}{ Total } & $216(49.1 \%)$ & $224(50.9 \%)$ & $440(100 \%)$ \\
\hline
\end{tabular}

\section{Reasons for Leisure Reading}

The students participating in the study were asked to indicate their motivations for leisure reading. An overwhelming majority (62\%) of the students said that most of the time they read to get better grades in their tests and examinations (Table 2). Improving language skills was another reason often cited by the respondents for 
reading non-study related books. Other common motivations for leisure reading 'most of the time' were: to learn more things (45.5\%), reading to relax $(41.4 \%)$, and reading is my hobby $(38.2 \%)$. Slightly over 20 percent of the students said that most of the time they read as their parents or teachers ask them to do so. It appeared that academically-related reasons such better grades and improving language skills were the main motives for leisure reading and only a limited number of the students were reading for relaxation.

Table 2. Reason for Reading

\begin{tabular}{|l|c|c|c|}
\hline \multicolumn{2}{|c|}{ Reason } & \multicolumn{3}{|c|}{ Frequency } \\
\cline { 2 - 4 } & Most of the Time & Sometimes & Rarely \\
\hline $\begin{array}{l}\text { For better grades in tests and } \\
\text { examinations }\end{array}$ & $273(62.0 \%)$ & $117(26.6 \%)$ & $50(11.4 \%)$ \\
\hline For improving my language skills & $270(61.4 \%)$ & $123(27.9 \%)$ & $47(10.7 \%)$ \\
\hline For learning new things & $200(45.5 \%)$ & $191(43.4 \%)$ & $49(11.1 \%)$ \\
\hline For relaxing & $182(41.4 \%)$ & $173(39.3 \%)$ & $85(19.3 \%)$ \\
\hline Reading is my hobby & $168(38.2 \%)$ & $140(31.8 \%)$ & $132(30.0 \%)$ \\
\hline For my homework and projects & $138(31.4 \%)$ & $229(52.1 \%)$ & $73(16.5 \%)$ \\
\hline When I have nothing else to do & $103(23.4 \%)$ & $172(39.1 \%)$ & $165(37.5 \%)$ \\
\hline $\begin{array}{l}\text { When my parents or teacher ask } \\
\text { me to read }\end{array}$ & $90(20.5 \%)$ & $141(32.1 \%)$ & $209(47.4 \%)$ \\
\hline
\end{tabular}

\section{Frequency of Leisure Reading}

The participating students were asked how frequently they engage in leisure reading. It was found that slightly over 80 percent of the students reported reading for fun at least once a week (Table 3). Some 47.3 percent of the students said that they read for fun almost daily while 13.9 percent were doing so every other day. The proportion of students who were doing fun reading only during school holidays was 19.2 percent.

Table 3. Frequency of Leisure Reading

\begin{tabular}{|l|c|c|c|}
\hline \multirow{2}{*}{ Frequency } & \multicolumn{2}{|c|}{ Number of respondents } & \multirow{2}{*}{ Total } \\
\cline { 2 - 3 } & Boys & Girls & \\
\hline Almost daily & $78(36.3 \%)$ & $129(57.8 \%)$ & $207(47.3 \%)$ \\
\hline Every other day & $31(14.4 \%)$ & $30(13.5 \%)$ & $61(13.9 \%)$ \\
\hline During weekends & $51(23.7 \%)$ & $35(15.7 \%)$ & $86(19.6 \%)$ \\
\hline During school holidays & $55(25.6 \%)$ & $29(13.0 \%)$ & $84(19.2 \%)$ \\
\hline
\end{tabular}




\begin{tabular}{|l|l|l|l|}
\hline Total & $215(100 \%)$ & $223(100 \%)$ & $438(100 \%)$ \\
\hline
\end{tabular}

It appeared that boys were less avid readers than girls. As compared to 57.8 percent girls, only 36.3 percent of the boys were reading daily for fun. It is possible that boys might have preferred engaging in other leisure activities than reading. Another interesting trend was observed where, as compared to 13 percent girls, over one-quarter of the boys said that they read for fun during school holidays. It is possible that during school working days, boys might be more involved in extracurricular activities, enrichment classes, or attending private tuition classes and, as a result, left with only limited time for leisure reading. It is possible that, during school holidays these boys were trying to catch up with their fun reading.

\section{Sources of Reading Materials}

The participating children were asked to indicate from where they get books for their leisure reading. It was found that 34 percent of the children were getting their leisure reading books from public libraries (Figure 1). Another 32 percent of the children mentioned that they buy their books from bookstores. Onequarter of the children said that they borrow books from their school library. This phenomenon could be attributed to rapid expansion of public library network in Singapore during the last two decades as well as the establishment of international mega-bookstores such as Borders and Kinokuniya. The increase in book-buying activity could also be due to the rising affluence in Singapore. It was, however, a matter of concern that only one-quarter of the surveyed students were borrowing materials from their school libraries. One possible reason could be the non-availability of professional teacher-librarians in the majority of primary schools in Singapore who can select and purchase more relevant and engaging leisure reading materials for young children.

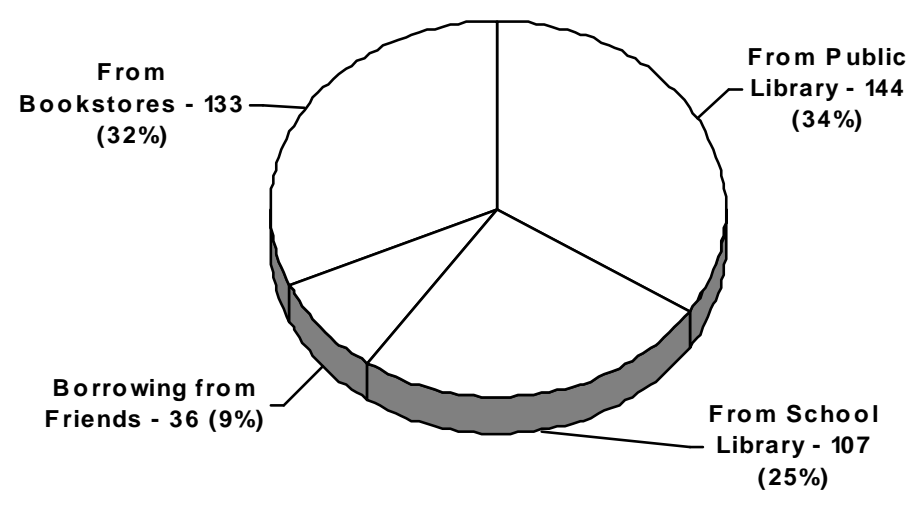

Figure 1. Preferred Sources for Getting Reading Materials 


\section{Preferred Place for Leisure Reading}

The students were asked to indicate where they often read their leisure materials. It was found that an overwhelming majority (64\%) of the students preferred doing their fun reading at home. Another 22 percent of the students mentioned that they do their leisure reading in school, while 5 percent of the students said that they read while travelling on Mass Rail Transit (MRT) trains, buses or in their cars. Only 4 percent of the students reported doing their leisure reading in public libraries. It was interesting to note that while the public libraries were the most likely place for borrowing leisure materials, a majority of the children were not using the library premises for reading. One possible reason could be that public libraries in Singapore are heavily used and probably it was difficult for these young children to easily get a comfortable place to sit and enjoy reading. Another possible explanation could be that parents of these children were too busy and unable to stay with their children at public libraries for a long duration of time and, therefore, were encouraging their children to borrow materials and read them at home.

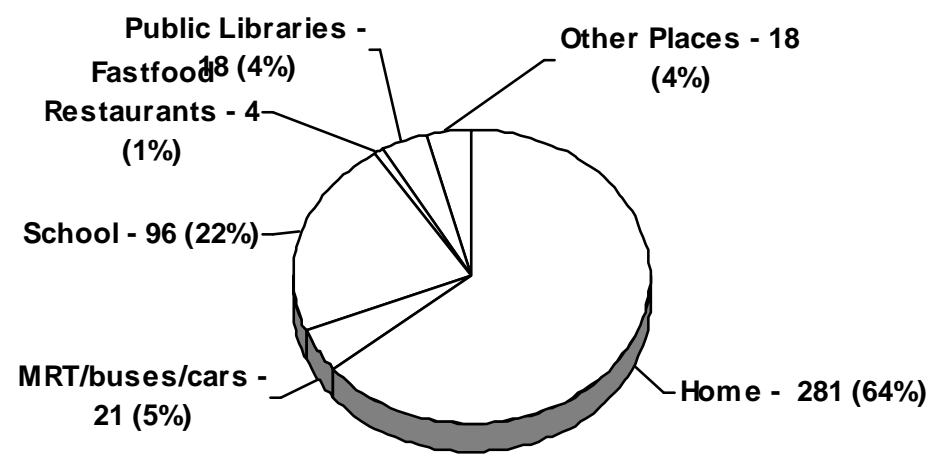

Figure 2. Preferred Place for Leisure Reading

\section{Preferred Type of Reading Materials}

The students were asked to indicate what type of materials they like to read. It was found that storybooks were the most preferred type of leisure time reading materials and 62.7 percent of the children reported reading such materials most of the time (Table 4). Comics also had a strong following with 45.7 percent of the children reading them most of the time. These were followed by magazines, the Internet and informational non-fiction books. So far as gender differences were concerned, more girls liked reading storybooks and magazines whereas boys preferred reading non-fiction books and comics.

Table 4. Preference for Reading Materials (multiple responses)

\begin{tabular}{|l|c|c|c|}
\hline \multirow{2}{*}{ Reason } & \multicolumn{3}{|c|}{ Frequency } \\
\cline { 2 - 4 } & Most of the Time & Sometimes & Rarely \\
\hline Storybooks & $276(62.7 \%)$ & $123(28.0 \%)$ & $41(9.3 \%)$ \\
\hline
\end{tabular}




\begin{tabular}{|l|c|c|c|}
\hline Comics & $201(45.7 \%)$ & $132(30.0 \%)$ & $107(24.3 \%)$ \\
\hline Magazines & $125(28.4 \%)$ & $148(33.6 \%)$ & $167(39.0 \%)$ \\
\hline Internet/ Websites & $124(28.2 \%)$ & $142(32.3 \%)$ & $174(39.5 \%)$ \\
\hline Information non-fiction books & $116(26.4 \%)$ & $200(45.5 \%)$ & $124(28.1 \%)$ \\
\hline Newspapers & $99(22.5 \%)$ & $202(45.9 \%)$ & $139(31.6 \%)$ \\
\hline
\end{tabular}

\section{Preferred Subject for Fiction Books}

For the fiction books, boys and girls alike showed a strong preference for mysteries and adventure books. Some 63 percent of the surveyed children reported reading mysteries and detective stories while another 60 percent were reading adventure stories (Table 5). Comedy and horror stories were also equally popular among these children. Comparatively less number of children was interested in reading storybooks on animals and relationships. It appeared that mysteries, crime, detective, and adventure were the most popular subjects among the children. Surprisingly, despite the popularity of Harry Potter books, science fiction and fantasy were not among the top three most preferred genres.

Table 5. Preferred Subjects for Fiction Books (multiple responses)

\begin{tabular}{|l|c|c|c|}
\hline \multirow{2}{*}{ Reason } & \multicolumn{3}{|c|}{ Frequency } \\
\cline { 2 - 4 } & Most of the Time & Sometimes & Rarely \\
\hline $\begin{array}{l}\text { Mysteries, crime \& detective } \\
\text { stories }\end{array}$ & $277(63.0 \%)$ & $113(25.6 \%)$ & $50(11.4 \%)$ \\
\hline Adventure stories & $264(60.0 \%)$ & $132(30.0 \%)$ & $44(10.0 \%)$ \\
\hline $\begin{array}{l}\text { Comedy (funny stories, jokes, } \\
\text { riddles, etc.) }\end{array}$ & $249(56.6 \%)$ & $131(29.8 \%)$ & $60(13.6 \%)$ \\
\hline Horror stories & $223(50.7 \%)$ & $115(26.1 \%)$ & $102(23.2 \%)$ \\
\hline Science fiction and fantasy & $150(34.1 \%)$ & $155(35.2 \%)$ & $135(30.7 \%)$ \\
\hline Fairytales and folktales & $152(34.5 \%)$ & $125(28.4 \%)$ & $163(37.1 \%)$ \\
\hline Animal stories & $116(26.4 \%)$ & $162(36.8 \%)$ & $162(36.8 \%)$ \\
\hline Stories about relationships & $91(20.7 \%)$ & $149(33.9 \%)$ & $200(45.4 \%)$ \\
\hline
\end{tabular}

So far as gender preference for different genres was concerned, no clear distinction was found as the top three subjects liked by boys and girls were the same. The girls preferred reading books on adventure, mysteries, and comedy as well as books on fairytales and relationships. On the other hand, boys preferred reading books on adventure, comedy and mysteries. The horror and science fiction books were equally popular among both the genders. On the other end of the scale, the boys least liked reading stories about relationships while girls were not much interested in fiction stories on animals. 
Among the non-fiction books, the most popular subject among the surveyed children was hobbies such as handicrafts and cooking (Table 6). In addition, books on animals and plants as well as those on sports were also very popular among these children. The preference for non-fiction books on animals and plants could be due to interest developed during science lessons which encouraged them to read more books on these topics. Similarly interest in sports, particularly among boys, could be due to extensive coverage given to sports by television channels. On the other hand, books on life and people in other countries were the least popular. It was not an expected finding as Singapore is a multi-cultural and multi-ethnic society with a large population of expatriates. It was expected that children would be more interested in knowing about other countries and cultures.

On the whole, as compared to boys, girls were less inclined to read non-fiction books. However, almost one-half of the girls said that most of the time they like reading books on handicrafts and cooking. The most preferred subject for boys, which obtained one of the lowest score from girls, was sports. This finding was not unexpected as generally boys show more interest in sports than girls. Boys also liked to read about science and supernatural phenomenon such as UFOs and aliens. The least preferred subjects among the boys were 'life and people in other countries' and 'history and geography'.

Table 6. Preferred Subjects for Non-fiction Books (multiple responses)

\begin{tabular}{|l|c|c|c|}
\hline \multirow{2}{*}{ Reason } & \multicolumn{3}{|c|}{ Frequency } \\
\cline { 2 - 4 } & Most of the Time & Sometimes & Rarely \\
\hline $\begin{array}{l}\text { Hobbies (handicrafts, } \\
\text { cooking, etc.) }\end{array}$ & $182(41.4 \%)$ & $150(34.1 \%)$ & $108(24.5 \%)$ \\
\hline Animals and plants & $168(38.2 \%)$ & $179(40.7 \%)$ & $93(21.1 \%)$ \\
\hline $\begin{array}{l}\text { Sports (field and in-door } \\
\text { sports, car racing, etc.) }\end{array}$ & $168(38.2 \%)$ & $110(25.0 \%)$ & $162(36.8 \%)$ \\
\hline $\begin{array}{l}\text { Science (inventions, } \\
\text { experiment, etc.) }\end{array}$ & $160(36.4 \%)$ & $163(37.0 \%)$ & $117(26.6 \%)$ \\
\hline UFOs and aliens & $128(29.1 \%)$ & $141(32.0 \%)$ & $171(38.9 \%)$ \\
\hline History and geography & $103(23.4 \%)$ & $151(34.3 \%)$ & $186(42.3 \%)$ \\
\hline $\begin{array}{l}\text { Life and people in other } \\
\text { countries }\end{array}$ & $86(19.5 \%)$ & $169(38.4 \%)$ & $185(42.1 \%)$ \\
\hline
\end{tabular}

\section{Preferred Leisure Activities}

The children were asked to select the three most favourite activities from a list of 8 common leisure pursuits and rank them according to their preferences. When all responses, regardless of their priority were considered, hobbies and sports came at the top as $257(60.9 \%)$ of the children selected it as one of their three favourite activities 
(Table 7). The second most popular activity was playing on computer or the Internet, with 57.6 percent of the children indicating it as one of their top 3 favourite activities. Reading came at the third position, just before watching television.

Table 7. Favourite Activities among Children (multiple responses)

\begin{tabular}{|l|c|c|c|c|}
\hline \multirow{2}{*}{\multicolumn{1}{|c|}{ Activity }} & \multicolumn{2}{|c|}{ Number of Respondents } & \multirow{2}{*}{ Total } \\
\cline { 2 - 4 } & $\mathbf{1}^{\text {st }}$ Choice & $\mathbf{2}^{\text {nd }}$ Choice & $\mathbf{3}^{\text {rd }}$ Choice & C \\
\hline Hobbies and sports & $80(19.0 \%)$ & $87(20.6 \%)$ & $90(21.3 \%)$ & $257(60.9 \%)$ \\
\hline $\begin{array}{l}\text { Playing on computer or } \\
\text { the Internet }\end{array}$ & $113(26.8 \%)$ & $64(15.2 \%)$ & $66(15.6 \%)$ & $243(57.6 \%)$ \\
\hline Reading & $73(17.3 \%)$ & $69(16.4 \%)$ & $44(10.4 \%)$ & $186(44.1 \%)$ \\
\hline Watching TV & $56(13.3 \%)$ & $59(14.0 \%)$ & $64(15.2 \%)$ & $179(42.4 \%)$ \\
\hline Playing or going out & $36(8.5 \%)$ & $68(16.1 \%)$ & $70(16.6 \%)$ & $174(41.2 \%)$ \\
\hline Listening music & $43(10.2 \%)$ & $66(15.6 \%)$ & $56(13.3 \%)$ & $165(39.1 \%)$ \\
\hline Sleeping & $19(4.5 \%)$ & $5(1.2 \%)$ & $24(5.7 \%)$ & $48(11.4 \%)$ \\
\hline Other activities & $2(0.5 \%)$ & $4(0.9 \%)$ & $8(1.9 \%)$ & $14(3.3 \%)$ \\
\hline \multicolumn{1}{|c|}{ Total } & $422(100 \%)$ & $422(100 \%)$ & $422(100 \%)$ & $1266(300 \%)$ \\
\hline
\end{tabular}

The boys and girls were spilt over their most favourite leisure activities. The top three favourite activities among boys, in the order of preference, were playing on computer or the Internet, engaging in hobbies or sports, and watching television. The order was the same regardless of whether total responses or only the first-choices were to be considered. Girls preferred participating in hobbies or sports, followed by reading and listening to music. However, when only the first-choices were considered, reading emerged as the most favourite leisure time activity for girls. These findings confirm that girls are generally more likely to enjoy reading than boys.

\section{Conclusion}

Reading is a basic skill which should be developed at an early age and nurtured continuously to help individuals become lifelong learners. One established way for improving the overall reading skills is through encouraging leisure reading. However, the findings of this study suggest that a majority of the students were reading to improve their academic performance. This could possibly be due to stressful Singapore education system which places high emphasis on meritocracy and good grades. Students often face pressure from their parents and teachers to improve their academic performance. The findings of this study suggest that probably even primary level students are not free from this pressure. Many children also expressed the wish to have more time for fun reading. It is, therefore, desirable that Singapore Ministry of Education (MOE) should consider reducing workload of primary school children so that they may find enough time for fun reading. 
Another dimension of this problem is that often children have a fixed amount of time and energy for leisure activities and, in addition to fun reading, many other activities are competing for their time and attention. Recent technological advancements such as affordable computers and other gadgets, cable television, improved connectivity to the Internet, enhanced capabilities of video and computer games, and the increasing popularity of SMS, chat rooms, discussion forums, blogs, and Wikis are influencing the reading habits of children. Teachers and parents can play an important role in educating children how to keep a balance in their leisure activities, including the fun reading. Similarly, school and public libraries need to make concerted efforts in providing access to more interesting and engaging reading materials.

\section{References}

Balasundram, S. (1991). A survey of children's reading interests. Singapore Book World, 20, 82-105. Books Aid International (2003). Is reading a dying pastime? Readers across in globe say no! [Press Release]. Retrieved November 8, 2006, from http://www.bookaid.org/cms.cgi/site/news/

Cheah, Y.M. (1998). Nurturing the Singapore reader. Reading, 32(1): 33-35.

Children's Books Ireland. (2000). What's the story: the reading choices of young people in Ireland. Retrieved Marc 1, 2006 from http://www.literacytrust.org.ok/databse/stats/readchild.html\#ireland

Cosgrove, M.S. (2001). Students' view on the purposes of reading from three perspectives - students, teachers and parents. $12^{\text {th }}$ European Reading Conference, July 1-4, 2001: Dublin, Ireland.

Cunningham, A.E. \& Stanovich, K.E. (1998). What reading does for the mind? American Educator, 22(1): 8-15.

Education Department (2001). Survey on the reading habits of students in Hong Kong. Retrieved March 27, 2007, from http://www.emb.gov.hk/index.aspx?nodeID=679\&langno=1

Hall, C. \& Coles, M. (1999). Children's reading choices. London: Routledge.

Liu, Z. (2000). Reading is on the rise in China. Retrieved March 3, 2006, from http://www.honco.net/100day/02/2000-0526-liu.html

Market \& Opinion Research International-MORI (2004). Retrieved on March 26, 2007, from http://www.ipsos-mori.com/polls/2003/nfm17.shtml

National Center for Education Statistics. (1993). NAEP 1992: Reading report card for the nation and the states. Report No. 23-ST06. Washington, DC

Ogle, L.T; Sen, A. \& Pahlke, E. (2003). International comparisons in fourth-grade reading literacy: Findings from the Progress in International Reading Literacy Study (PIRLS) of 2001. Retrieved on March 26, 2007, from http://nces.ed.gov/pubs2003/2003073.pdf

Royce, J. (1995). Lifelong reading element \#4: Interest and enjoyment. Retrieved on March 13, 2005 , from http://vm.robcol.k12.tr/ jroyce/read6.htm

Shefelbine, J. (1998). Literacy as a way of life. Retrieved on March 26, 2007, from http://teacher.scholastic.com/products/readingcounts/pdfs/reading_voluminously.pdf

Steffensen, A. \& Weinreich, T. (2000). Children read books: Reading habits, reading ability, reading aloud (summary). Retrieved on March 28, 2007, from http://www.cfb.dk/site.aspx?p=301

Sturm, B.W. (2003). The information and reading preferences of North Carolina children, School Library Media Research, volume 6. Retrieved on March 26, 2007, from http://www.ala.org/ala/aasl/aaslpubsandjournals/slmrb/slmrcontents/volume62003/readingpref erences.htm

Times Educational Supplement (2000). Boys drop books in favour of computer and TV. Retrieved on March 25, 2007, from http://www.literacytrust.org.uk/database/boys/english.html

Woolcott Research. (2001). Young Australian reading: From keen to reluctant readers. Retrieved on march 26, 2007, from http://www.slv.vic.gov.au/pdfs/aboutus/publications/yar_report.pdf 


\section{Bibliographic Notes}

Shaheen Majid is Associate Professor at the Division of Information Studies, Wee Kim Wee School of Communication and Information, Nanyang Technological University, Singapore. Email: asmajid@ntu.edu.sg

Venus Tan was a graduate student at the Division of Information Studies, Wee Kim Wee School of Communication and Information, Nanyang Technological University, Singapore. 